\title{
Delamination of Kaolinite by Mechano-chemical Grinding
}

by Kinue TSUNEMATSU ${ }^{1}$, Hiroshi TATEYAMA ${ }^{1}$ and Kunio KIMURA ${ }^{1}$

1. Kyushu National Industrial Research Institute, 807-1 Shuku-machi, Tosu-shi, Saga 841-0052

\begin{abstract}
Kaolinite was treated with urea to form urea-kaolinite complex, then delaminated by grinding using a mechanical mortar. The delaminated products and their deintercalated products were characterized by specific surface area measurement, X-ray diffraction and infrared absorption analysis. The results are summarized below.

The specific surface area of the kaolinite treated with urea remarkably increased by grinding for more than $3 \mathrm{~h}$. The basal spacing of the treated kaolinite increased due to the intercalation of urea into the kaolinite structure, and the decrease in attractive force acting between silicate layers of kaolinite. It caused that kaolinite was easily delaminated by grinding. The basal spacing of urea-kaolinite complex was decreased from $10.8 \AA$ to $8.3 \AA$ by boiling and washing. The $8.3 \AA$ basal spacing is larger than the kaolinite (7.2 $\AA$ ). This result indicates that a molecule decomposed from urea (NHCO) still remains in the kaolinite structure.
\end{abstract}

KEY WORDS : Delamination, Urea, Kaolinite, Intercalation, Grinding, Mechano-chemical

\section{1. 緒言}

陶磁器用配合原料としてカオリナイト質粘土を用いる場合, 粘 土特有の可塑性は, 陶磁器の成形性や強度等に大きな影響を与え ている。高の可塑性を左右する因子の一つに粘土粒子の厚さがあ り, 粘土の分散・凝集性およびレオロジー特性等 ${ }^{1)}$ の観点から , 厚さは薄い方が可塑性は高いと考えられる。すでに, 筆者らはカ オリナイト粒子の薄層化方法について, カオリナイト層間に尿素 をインターカレートさせ, 湿式ボールミル粉砕することで比表面

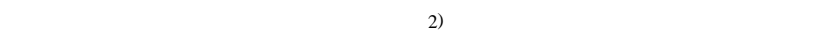
素一カオリナイト層間化合物を尿素溶液中で煮沸・䚌拌して層間 剥離させることで, 比表面積の值を大きくできることを報告 ${ }^{3)} し$ ている。しかし, ,ずれの場合も比表面積の值は $20 \mathrm{~m}^{2} / \mathrm{g}$ 程度の 増加しか認められていない。

本報告では , カオリナイト層間へ尿素をインターカレートさせ た尿素ーカオリナイト複合体をさらに乾式摩砕することにより， 比表面積の值を著しく増加させる方法について述べる。さらに， X 線回折法および赤外線吸収スペクトル測定の結果から,脱イン ターカレーションに伴う尿素の挙動およびカオリナイト構造の 変化についても検討したので報告する。

\section{2．試料および実験方法}

鹿児島県入来鉱山産のカオリン原料を粒度 $44 \mathrm{~mm}$ 以下にふるい 分け Fig. 1 に示す方法で実験を行った。試料 $5 \mathrm{~g}$ に対し，尿素を

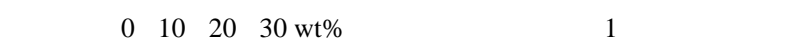
摩砕後は尿素を短時間で十分にインターカレートさせるために，

* 1999 年 5 月 10 日受付 9 月 27 日受理 資源 ·素材学会 1999 年春季大会にて 一部発表

1. 正会員 九州工業技術研究所 主任研究官 ファイン素材部

2. 理博 九州工業技術研究所 研究企画官

3. 正会員 工博 九州工業技術研究所 粉体プロセス研究室長

[ 著者連絡先] FAX 0942-83-0850 (九工技研)

キーワード: 薄層化, 尿素, カオリナイト, インターカレーション, 乾式摩砕

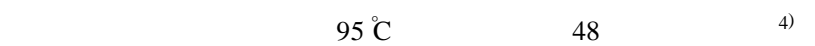
得られた無添加試料および尿素一カオリナイト複合体の出発試 料 (In44) は，機械乳鉢で 1，3，5 時間の乾式摩砕後, 煮沸および 遠心分離器による洗浄を繰り返した。また， $44 \mathrm{~mm}$ 以下の試料を さらに $5 \mathrm{~mm}$ で粒度区分した細粒子 (InF) と粗粒子 (InC) の試料に ついても同樣な乾式摩砕, 者沸・洗浄を行い, 粒度の影響を比較 した。

機械乳鉢は日陶科学 (株) 製の自動乳鉢 ANM-150 形を用いた。 また , 比表面積測定にはカンタクローム社製オートソーブ-1-AG

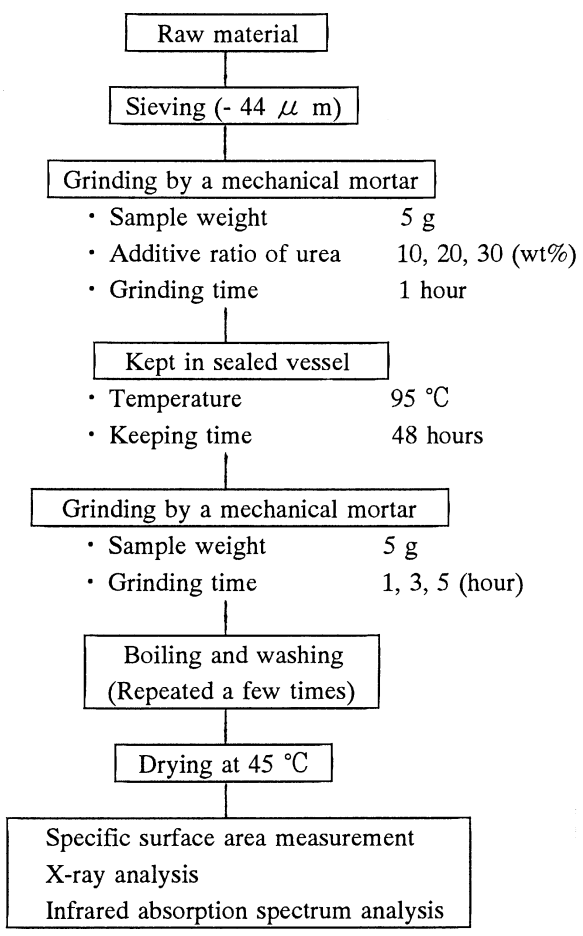

Fig.1 Experimental method. 
を用い，BET 法により測定した。X 線回折法による定性分析は フィリップス社製 APD15 を用い, 電圧 $30 \mathrm{kV}$, 電流 $20 \mathrm{~mA}$, ス リット幅 $1^{\circ}-1^{\circ}-0.3 \mathrm{~mm}$ の条件で測定した。なお，尿素のイン ターカレーション (IC) 反応率は Weiss らの方法 ${ }^{5)}$ に従い, カオリナ イト $(001)$ 反射 $(\mathrm{d}=7.2 \AA)$ の積分強度 $\left(\mathrm{I}_{7.2 \AA}\right)$ と尿素のインターカ レーションにより生じた $(001)$ 反射 $(\mathrm{d}=10.8 \AA)$ の積分強度 $\left(\mathrm{I}_{10.8 \AA}\right)$ を測定し， $\mathrm{I}_{10.8 \AA} /\left(\mathrm{I}_{7.2 \AA}+\mathrm{I}_{10.8 \AA}\right)$ の式により求めた。ついで，カオリ ナイトの結晶度を表す Hinckley 指数 ${ }^{6)}$ も測定した。また , 赤外線 吸収スペクトルの測定にはパーキンエルマー社製FTIR1760X を用 い, 臭化カリウム錠剂法により行った。

\section{3. 結果と考察}

\section{3 - 1 尿素-カオリナイト複合体の IC 反応率測定}

In44 の尿素 - カオリナイト複合体を乾式摩砕し, IC 反応率に及 ぼす尿素添加割合と摩砕時間の影響について調べた。結果をFi g. 2 に示す。尿素 $10 \mathrm{wt} \%$ 添加試料の場合， 0.80 の IC 反応率は 1 時間 摩砕で 0.85 ,3 時間摩砕で 0.88 とわずかずつ大きくなっているが， 5 時間摩砕しても光の值は光れ以上に変化しなかった。また，尿 素を $20 \mathrm{wt} \%, 30 \mathrm{wt} \%$ 添加した試料の IC 反応率は 0.89 から，1 時 間摩砕でともに $0.91,3$ 時間摩砕でとれ㶢れ $0.98,0.97$ と大きく なった後，ほぼ一定となった。尿素添加割合および摩砕時間を増 大しても IC 反応率に大きな変化か認められないのは, 出発試料で ある尿素 - カオリナイト複合体のカオリナイト層間に, ほとんど の尿素が保持された状態にあるためと考えられる。

\section{$3 \cdot 2$ メカノケミカル摩砕}

In44 を所定時間乾式摩砕した後, 煮沸・洗浄して比表面積測定 を行った。結果を Fi g. 3 に示す。無添加試料の比表面積は摩砕時 間の影響がほとんど認められないが，尿素添加試料の場合は，摩 砕時間の増大とともに兴の值も増加している。尿素 $10 \mathrm{wt} \%$ 添加 試料の比表面積は 3 時間摩砕までは, 初期の $16 \mathrm{~m}^{2} / \mathrm{g}$ から $27.9 \mathrm{~m}^{2}$ /g まで徐々に増加しているが, 5 時間摩砕ではほとんど変化しな かった。尿素 $20 \mathrm{wt} \%$ 添加試料では，3 時間摩砕まで比表面積は 徐々に増加しているが, 5 時間摩砕で急激に増加し, $65.6 \mathrm{~m}^{2} / \mathrm{g}$ の 最大值を示している。また，尿素 $30 \mathrm{wt} \%$ 添加試料の場合は 3 時 間摩砕まで急激な比表面積の増加が認められるが, 兴の後は緩や かに増加している。

これらの結果については以下のように考察される。カオリナイ 卜層間に尿素が十分にインターカレートすると，層間距離は拡大 し, 層間力は小さくなると考えられる。この状態で乾式摩砕を繰 り返すと，インターカレートした尿素はカオリナイト単位層をお 互いに滑りやすくし，カオリナイト粒子の薄層・微粒子化を進行 させるために, 比表面積が大きくなると推察される。また，尿素 添加割合が増加すると，インターカレートしていない過剩な尿素 は粒子の回りに付着し, 乾式摩砕する際に粒子同士を滑りやすく していると考えられる。一方, 無添加試料の場合, カオリナイト 単位層は規則的な積層状態を保持しているために, カオリナイト

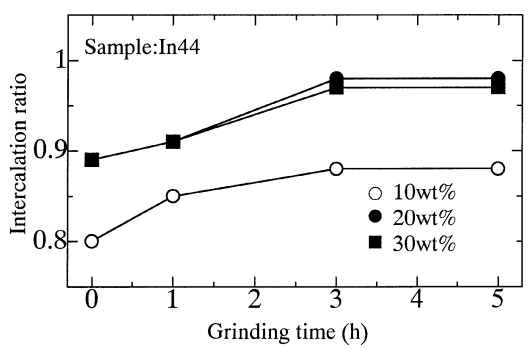

Fig.2 Intercalation ratio of urea into kaolinite as a function of grinding time.

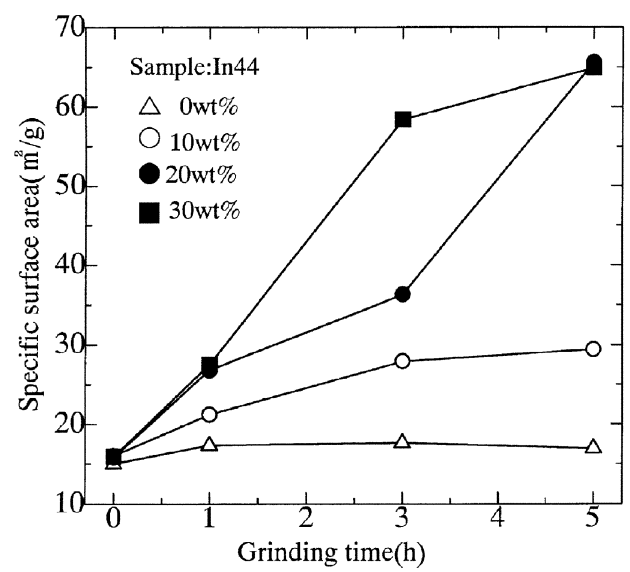

Fig.3 Specific surface area plotted against grinding time and additive ratio of urea.

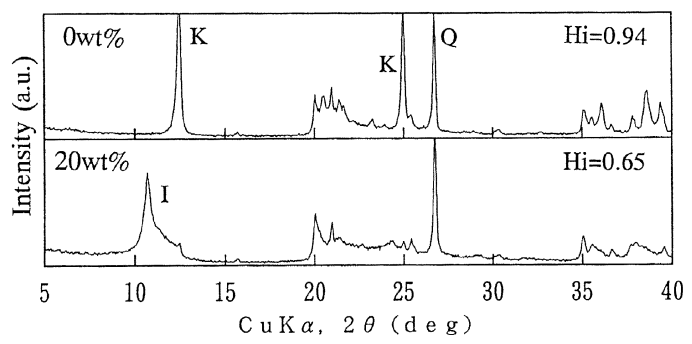

Fig.4 X-ray powder diffraction patterns of In44 after grinding for five hours ( Hi: Hinckley index, K: Kaolinite, Q: Quartz, I: Complex of NHCO and kaolinite).

単位層の乱れはなく，摩砕によるクラックが粒子表面に発生し， 粒子がわずかに摩砕されると推察される。

以上のことは Fi g. 4 に示した 5 時間摩砕後に煮沸・洗浄した試 料の X 線回折パターンおよび Hinckley 指数からも類推できる。無 添加試料の場合，(001) 反射ならびに (hkl) 反射ピークはシャープ なパターンを示しているが, 尿素添加試料は無添加試料に比べ (001) 反射ピークは小さくなり,(hkl) 反射ピークはブロードになっ ている。カオリナイトの積層不整の程度を表すと考えられる Hinckley 指数も 0.94 から 0.65 と小さくなっていることから, カオ リナイト層間にインターカレートした尿素は, 摩砕によりカオリ ナイト単位層を乱し, 積層不整を生じさせていることがわかる。 また，無添加試料と尿素添加試料の間で石英のピーク強度にほと んど変化がないことから, 選択的にカオリナイトのメカノケミカ ル摩砕が行われていると考えられる。なお， 2 q = $10.6^{\circ}(\mathrm{d}=8.3$ Å)に認められる新たなピークは，後述するように煮沸・洗浄によ り尿素の一部が分解し, 新たに生成した NHCO からなる尿素分解

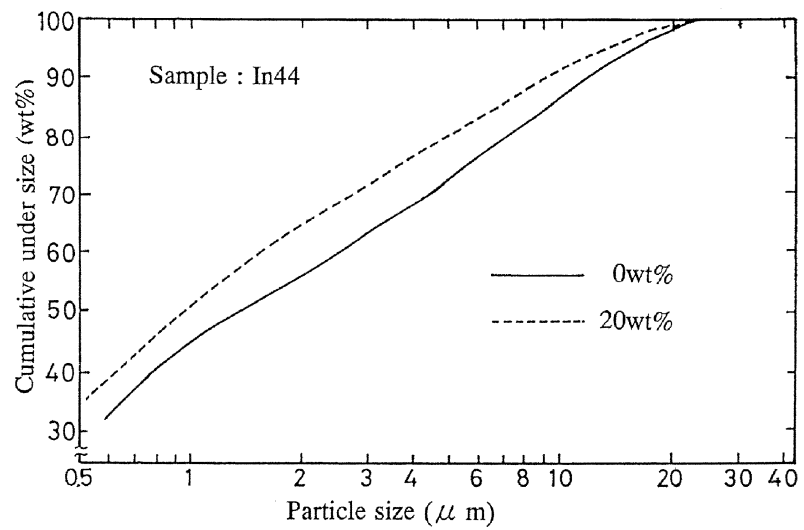

Fig.5 Particle size distribution of samples after grinding for five hours. 


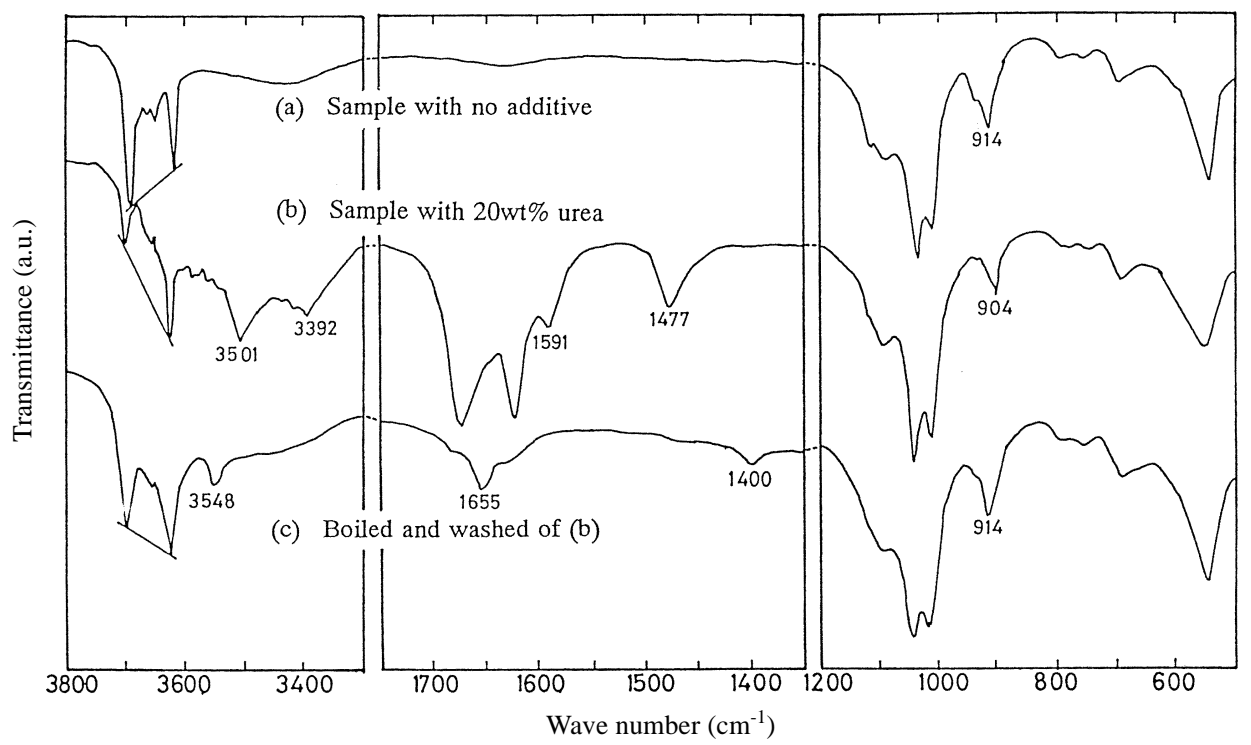

Fig.6 Infrared absorption spectra of the sample after grinding for five hours ( In44).

生成物によるものと考えられる。両試料の粒度分布を Fi g. 5 に示 す。無添加試料の平均粒子径が $1.27 \mathrm{~mm}$ に対し , 尿素 $20 \mathrm{wt} \%$ 添加 試料の弚れは $0.97 \mathrm{~mm}$ と小さくなっている。

$3 \cdot 3$ 赤外線吸収スペクトル測定による尿素の挙動

5 時間摩砕した In44 について, 尿素の挙動およびカオリナイト 構造の変化を調べるために赤外線吸収スペクトル測定を行った。 結果を Fi g. 6 に示す。(a) は無添加試料 , (b) は尿素 $20 \mathrm{wt} \%$ 添加試 料，(c) は（b) を煮沸・洗浄した試料のスペクトルである。(a) と (b) からわかるように, 尿素のインターカレーションによって , カ オリナイトの $\mathrm{OH}$ 伸縮振動に帰属される $3,698 \mathrm{~cm}^{-1}$ のピークと $3,620 \mathrm{~cm}^{-1}$ のピークの頂点を結ぶ直線の傾斜の向きが逆転し，尿 素の NH 伸縮振動に帰属される $3,438 \mathrm{~cm}^{-1}$ と $3,344 \mathrm{~cm}^{-1}$ のピーク は, $3,501 \mathrm{~cm}^{-1}$ と $3,392 \mathrm{~cm}^{-1}$ の高波数にシフトしている。また， 尿素の $\mathrm{NH}$ 変角振動に帰属される $1,609 \mathrm{~cm}^{-1}$ のピークは (b) では $1,591 \mathrm{~cm}^{-1}$ の低波数にシフトしている。

これらの結果は Ledoux らの実験結果 ${ }^{7)}$ とほぼ一致している。す なわち,インターカレートした尿素分子の $\mathrm{NH}_{2}$ 基はカオリナイト の層面にある $\mathrm{O}, \mathrm{OH}$ と水素結合をしていると考えられる。しか し 尿素の CN 伸縮振動に帰属される $1,468 \mathrm{~cm}^{-1}$ のピークは (b) に おいて $1,477 \mathrm{~cm}^{-1}$ の高波数にシフトしており,Ledoux らの実験結 果とは異なっている。 $\mathrm{NH}$ 伸縮振動や $\mathrm{CN}$ 伸縮振動に帰属される ピークの高波数へのシフトは, インターカレートした尿素の $\mathrm{NH}$ 結合や CN 結合が尿素単味の場合より強くなったためと考えられ る。つまり，尿素分子同士が水素結合している尿素単味に対し， カオリナイト層間にインターカレートしている尿素が，尿素分子 間の結合を切断してカオリナイト層面と水素結合するために，尿 素単分子内の各原子間の結合か強〈なっていると考えられる ${ }^{4)}$ 。

$\mathrm{X}$ 線回折パターンで $2 q=10.6^{\circ}(\mathrm{d}=8.3 \AA)$ の位置にピークが 認められた。これは NHCO からなる新たな尿素分解生成物が生 じ, 弚れが層間に残存していると考えられるため, 無添加試料と 尿素 $20 \mathrm{wt} \%$ 添加試料について C と N の分析を CN コーダー法に より行った。無添加試料の C と N は光れ光れ $0.07 \mathrm{wt} \%, 0.04 \mathrm{wt} \%$ に対し，尿素 $20 \mathrm{wt} \%$ 添加試料の乥れは $0.11 \mathrm{wt} \%, 0.30 \mathrm{wt} \%$ とな り，尿素分解生成物が残存していると推察される。

この現象については (b) を煮沸・洗浄した赤外線吸収スペクト ル (c) からも確認できる。カオリナイト層間に尿素がインターカ レートすると，尿素とカオリナイトの $\mathrm{Al}(\mathrm{OH})$ とが水素結合して，
Al-OH 伸縮振動に帰属される $914 \mathrm{~cm}^{-1}$ のピークは $904 \mathrm{~cm}^{-1}$ ヘシ フトする。しかし，煮沸・洗浄した (c) では, このピークは 914 $\mathrm{cm}^{-1}$ と元の位置に戻っている。また, $\mathrm{NH}$ 変角振動に帰属される $1,591 \mathrm{~cm}^{-1}$ のピークは (c) では消滅している。これらの結果は, イ ンターカレートした尿素分子の $\mathrm{NH}_{2}$ 基とカオリナイトの $\mathrm{OH}$ の間 で生じる $\mathrm{N} \cdots \mathrm{H}$ 結合が, 者沸・洗浄により切断されたことを示唆 している。また，CO 伸縮振動に帰属されるピークが $1,655 \mathrm{~cm}^{-18)}$ に認められ，NH 伸縮振動に帰属されるピークは $3,548 \mathrm{~cm}^{-1}$ に認 められる。この $3,548 \mathrm{~cm}^{-1}$ のピークは尿素の $3,501 \mathrm{~cm}^{-1}$ の NH 伸 縮振動によるピークよりも高波数にシフトしている。さらに, CN 伸縮振動に帰属されるピークは $1,400 \mathrm{~cm}^{-1}$ に認められるが，尿素 中の光のピーク $1,477 \mathrm{~cm}^{-1}$ より低波数にシフトしている。このよ うに, 者沸・洗浄によって $\mathrm{NH}$ 結合は強くなり， $\mathrm{CN}$ 結合は弱く なったことから, $2 q=10.6^{\circ}(\mathrm{d}=8.3 \AA ̊ 0)$ の反射ピークは, $\mathrm{NHCO}$ からなる尿素分解生成物が残存していると考えられる。

\section{4 粒度の影響}

Fi g. 7 に 5 時間摩砕した InF と InC の比表面積測定結果を示す。 InF の場合， Fig.3 で示した 5 時間摩砕後の In44 に比べ, 無添加試 料の比表面積は若干大きくなっているものの，尿素添加試料につ いては両者の值はほぼ同じであり，尿素添加割合の増大に伴い類 似の増加傾向を示している。これは In44 試料中の約 $70 \mathrm{wt} \%$ が 5 $\mathrm{mm}$ 以下の粒度のためと考えられる。 InC については尿素添加割合 が増加するに従い比表面積が急激に増加することから，摩砕時間 の影響についても調べた。なお， IC 反応率は尿素 $10 \mathrm{wt} \%$ 添加試 料で 0.89 , 尿素 $20 \mathrm{wt} \%, 30 \mathrm{wt} \%$ 添加試料で 0.98 を示し，摩砕を 繰り返しても光の值は変化しなかった。これより, 粗粒子である カオリナイト粒子へは尿素が短時間で容易にインターカレートし ていることがわかる。

Fi g. 8に摩砕時間を変化させたときの比表面積測定結果を示す。 無添加試料の場合でも摩砕時間の増加とともに比表面積の值はわ ずかに大きくなっていることから，この粒度のカオリナイト粒子 は摩砕されやすいことがわかる。また , 5 時間摩砕後の比表面積 は尿素 $10 \mathrm{wt} \%$ 添加試料では初期の $16.0 \mathrm{~m}^{2} / \mathrm{g}$ から $51.8 \mathrm{~m}^{2} / \mathrm{g}$ と約 3 倍以上の増加を示し, 尿素 $20 \mathrm{wt} \%$ 添加試料では $84.9 \mathrm{~m}^{2} / \mathrm{g}$ と約 5 倍になっている。さらに, 尿素 $30 \mathrm{wt} \%$ 添加試料では $115.9 \mathrm{~m}^{2}$ / $\mathrm{g}$ の最大值を示している。InC の場合 , カオリナイト層間に容易に インターカレートした尿素は, 摩砕する際のカオリナイト単位層 


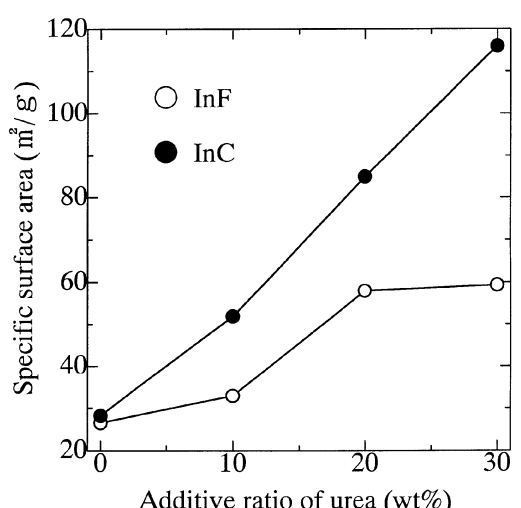

Fig.7 Specific surface area plotted against additive ratio of urea after grinding for five hours.

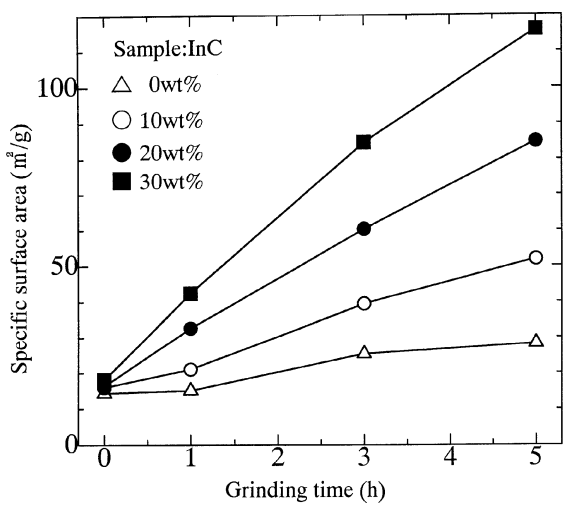

Fig.8 Specific surface area plotted against grinding time and additive ratio of urea.

を大きく乱し，層間力を小さくして，単位層はさらに滑りやすく なったと推察される。

以上のことを確認するために, $\mathrm{InF}$ の無添加試料および尿素 30 $\mathrm{wt} \%$ 添加試料を 5 時間摩砕後に者沸・洗浄し，ふるるい分けて得た $5 \mathrm{~mm}$ 以下の試料について SEM 観察を行った。試料の SEM 写真を Fi g. 9 に示す。無添加試料 (上) では六角板状の形態や，破砕され た微粒子の凝集物が観察されるが, 尿素添加試料 (下) では粒子形 態が不明瞭であり，フィルム状に連なったものか観察されることか ら，カオリナイト粒子は薄層・微粒子化していると考えられる。

$$
\text { 4. 結言 }
$$

カオリナイト層間へ尿素をインターカレートさせた尿素 - カオ リナイト複合体をメカノケミカル摩砕し, 比表面積の值を増加さ せる方法について述べた。また，X 線回折法および赤外線吸収ス ペクトル測定の結果から, 脱インターカレーションに伴う尿素の 挙動およびカオリナイト構造の変化についても検討した。結果を 以下に要約する。

1）尿素一カオリナイト複合体を乾式摩砕すると，比表面積の 值は著しく増加した。カオリナイト層間に尿素が十分にインター
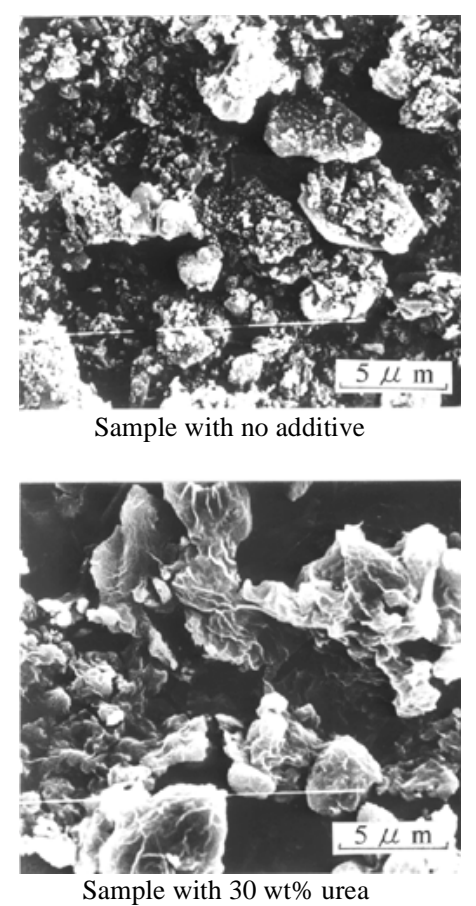

Fig.9 SEM photographs of samples sieved after grinding for five hours (Inc).

カレートすると, 層間距離は拡大し, 層間力は小さくなると考え られる。この状態で乾式摩砕を繰り返すと, 尿素がカオリナイト 層をお互いに滑りやすくするために, 粒子は薄層・微粒子化して いくと推察される。

2）尿素一カオリナイト複合体の面間隔は $10.8 \AA$ を示すが , 煮 沸・洗浄により $8.3 \AA$ に減少する。この $8.3 \AA$ はカオリナイトの面 間隔 $(7.2 \AA)$ より大きい。このことは, インターカレートした尿素 分子の $\mathrm{NH}_{2}$ 基とカオリナイトの $\mathrm{OH}$ の間で生じる $\mathrm{N} \cdots \mathrm{H}$ 結合が， 煮沸・洗浄により切断され, カオリナイト層間に尿素の一部が分 解して生成した NHCO が残存していることを示している。

終わりに，本研究を行うに当たり，粒度分布測定をしていただ いた長崎県害業技術センターの山口氏に感謝の意を表する。

\section{引用文献}

1) Tateyama, H., Nishimura, S., Tsunematsu, K., Jinnai, K. and Imagawa, K. : Ultrastructure Processing of Advanced Ceramics (John Wiley \& Sons, New York), p. 453-462, (1988) 2）恒松絹江·立山 博・西村 聡・陣内和彦: 日本セラミックス協会学術論文誌, Vol. 100, p. 178-181, (1992)

3) 松井 明・石黑智明: 富山県工業技術センター研究報告, No. 7, p. 1-3, (1993)

4) 恒松絹江 ·立山 博·西村 聡: 粘土科学, Vol. 34, No. 4, p. 228-234, (1995)

5) Weiss, A., Thielepape, W., Ritter, W., Schäfer, H. and Göring, G. : Zeit für anorg. und all. Chem., Vol. 320, p. 183-204, (1963)

6）岩生周一・長沢敬之助・宇田川重和・加藤忠蔵・喜田大三 : 青柳宏一・渡邊 裕：粘土の事典, 初版, 朝倉書店 (東京) p. 375-376, (1985)

7) Ledoux, R. L. and White, J. L. : Colloid Interface Sci., Vol. 21, p. 127-152, (1966)

8）名取信策・千原吳郎: 赤外線吸収スペクトル入門, 化学同人(株)(東京), 90 p.,(1966) 